\title{
Pendekatan Rancangan Museum Tenas Effendy Terhadap Prinsip-Prinsip Arsitektur Melayu
}

\author{
Adha Suhendri, Hendri Silva, S.T.,M.T., Ir. Sudarmin, M.T. \\ Program Studi Arsitektur, Fakultas Teknik, Universitas Lancang Kuning \\ Jl. Yos Sudarso km. 8 Rumbai, Pekanbaru, Telp. (0761) 52324 \\ Email: suhendriadha@gmail.com, hendri@unilak.ac.id, sudarmin@unilak.ac.id
}

\begin{abstract}
ABSTRAK
Tenas Effendy merupakan seorang budayawan yang terkenal di provinsi riau. Karya-karya Tenas Effendy banyak digunakan dalam memajukan kebudayaan melayu provinsi riau.Karya tenas Effendy yang paling terkenal adalah Tunjuk Ajar Melayu. Untuk mengenang jasanya serta menyimpan karya-karya Tenas Effendy tersebut maka diperlukan upaya dalam merencanakan sebuah museum.

Tujuan Perencanaan ini agar tersusunnya sebuah Planning dan Programing serta konsep rancangan museum Sasaran dari perencanaan museum Tenas Effendy adalah bagaimana museum tersebut dapat mewadahi karyakarya, mewadahi aktifitas museum, mewadahi sebuah tempat kegiatan edukatif, mewadahi kegiatan rekreatif, Serta mewadahi tempat pemajangan karya-karya Tenas Effendy sendiri.

Untuk merencanakan museum perlu adanya pembahasan terhadap aspek manusia, Fungsi, Lingkungan dan tapak serta bangunan yang kemudian dilakukan analisis.

Adapun hasil akhirnya adalah Tersusunnya Planning dan Programing serta konsep perancangan museum tenas effendy terhadap pendekatan prinsip-prinsip arsitektur melayu yang selanjutnya dalam bentuk desain dan 'rancangan.
\end{abstract}

Kata Kunci: Tenas Effendy, Museum, Arsitektur Melayu,, Konsep,Perancangan.

\begin{abstract}
Tenas Effendy is a famous humanist in Riau province. The works of Tenas Effendy are widely used in advancing Malay culture in Riau province. Effendy's most famous work is the Malay Teachings. To commemorate his services and save the works of the Tenas Effendy, an effort is needed to establish a museum. To set up a museum, there is a need for consideration of human aspects, site aspects or environment and building aspects. The purpose of planning this museum is to create a Planning and Programing of a museum which will facilitate the establishment of the museum.

The method used in planning the Tenas Effendy museum is how the museum can accommodate works, accommodate museum activities, accommodate a place of educational activities, accommodate recreational activities, and accommodate the display of the works of Tenas Effendy itself. The end result is the Arrangement of Planning and Programming as well as the concept of museum design tenas effendy on the Malay architectural principles approach which is then outlined in the design and design.
\end{abstract}

Keywords: Tenas Effendy, Museum, Malay Architecture, Malay, Concept,Design. 


\section{PENDAHULUAN}

Berdasarkan Peraturan Pemerintah RI No. 19 Tahun 1995, museum merupakan lembaga, tempat perawatan, penyimpanan, pemanfaatan dan pengamanan benda berupa bukti materil hasil karya manusia dan alam serta lingkungan guna pelestarian dan perlindungan kekayaan budaya bangsa.Di riau sendiri terdapat tokoh budaya melayu yang mana memiliki berbagai macam karya yang patut dilestarikan. Telah ada rencana pemerintah riau dalam menjadikan provinsi riau sebagai pusat kebudayaan melayu di asia tenggara. Oleh sebab itu kedepannya diharapkan bagi pemerintah dalam membangun museum yang dikhusukan untuk menyimpan, merawat berbagai macam karya dari toko budaya melayu Tenas Effendy (Sumber : http://belajaritutiadaakhir.blogspot.co.id/2011/08/mu seum-di-indonesia.html)

\section{METODE PENELITIAN}

Metode yang di gunakan adalah pengumpulan datadata yang terkait dengan perencanaan dan perancangan Museum.

\subsection{Studi Literatur}

Mengumpulkan data dari perpustakaan berupa karya ilmiah baik berupa buku-buku yang berhubungan dengan perencanaan dan perancangan mengenai museum.

\subsection{Studi Banding}

Melakukan peninjauan langsung ke museum Sang Nila Utama pekanbaru

\subsection{Wawancara}

Melakukan wawancara kepada pihak Museum Sang Nila Utama, serta keluarga Tenas Effendy dan Orang orang tua yang mengenal sosok tokoh Tenas Effendy.masyarakat jalan tanjung datuk

\subsection{Studi Empiris}

Melakukan pengumpulan data dengan referensi proyek sejenis terkait dengan bangunan "Museum $\mathrm{H}$. Tenas Effendy" baik langsung maupun tidak langsung, majalah, melalui internet, artikel

\section{HASIL DAN PEMBAHASAN}

Pekanbaru terletak di Provinsi Riau, Pekanbaru sendiri merupakan ibukota dari provinsi riau yang saat ini sedang berkembang pesat dalam pembangunan berbagai macam insfrastruktur. Di pekanbaru saat ini hanya terdapat satu museum yaitu museum Sang Nila Utama yang mana museum ini lebih mengarah terhadap penyimpanan benda benda umum. Maka atas dasar itu nantinya pemerintah dapat berorientasi terhadap pembangunan museum khusus.Museum tenas Effendi nantinya dapat direncanakan di jalan Tanjung Datuk, dimana lokasi ini memiliki bagian histori dalam berkembangnya kebudayaan melayu di pekanbaru.. (Sumber: Survey lapangan dan wawancara)

Pengambilan site dilokasi dijalan tanjung datuk memiliki potensi serta berdasarkan pertimbangan pertimbangan .

Nama Resmi : J1 Tanjung Datuk

Kecamatan : Lima Puluh

Kabupaten/kota : pekanbaru

Provinsi : Riau

Batas Wilayah

Utara : berbatasan langsung witama School

Timur : berbatasan dengan ruko

Selatan : berbatasan dengan perletakan peti kemas

Barat : berbatasan dengan sungai siak

Luas Site: $1.2 \mathrm{Ha}$

\subsection{Analisis Tapak}

Lahan yang dimamfaatkan untuk site seluas 1.2 Ha yang merupakan tanah kosong yang berisi beberpa vegetasi yang tumbuh serta banyak ditumbuhi rerumputan. Site sendiri memiliki potensi sebagai tempat membangun museum yang berubungan dengan melayu dikarnakan lokasi tersebut merupakan salah satu tempat berkembangnya budaya melayu sehingga site tersebut sangat baik untuk perletakan museum berorientasi pada melayu.selain itu dengan kondisi site yang terletak di tepian sungai siak maka memiliki potensi view yang baik.

\subsubsection{Dimensi Tapak}

Pengambilan ukuran tapak berdasarkan perhitunganperhitungan terhadap analisa program dan kebutuhan ruang, luas sitenya adalah.

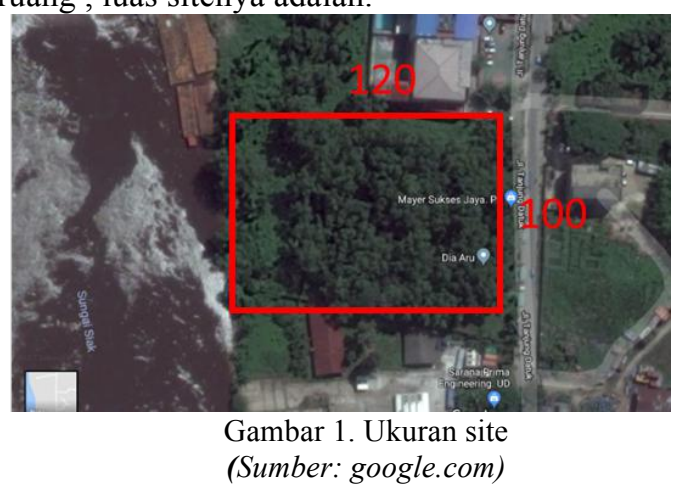

\subsection{Analisis view}

Orientasi atau view terbaik adalah mengarah kebarat dikarnakan pada barat sendiri terdapat potensi sungai siak yang mana nantinya sungai siak dapat dijadikan view pemandangan yang indah,selain itu pada barat bisa dijadikan potensi untuk pencapaian apabila pengunjung datang menggunakan jalur air. 


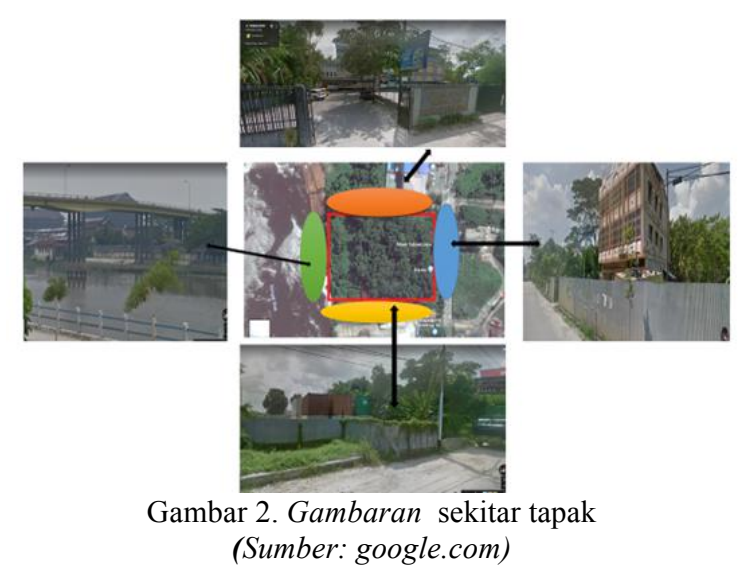

\subsection{Analisis Topografi}

Jenis tanah yang terdapat pada lokasi site adalah tanah yang lumayan cukup keras dimana tanah lokasi site merupakan tanah yang mengandung kerikil dan pasir, namun pada bagian tertentu terdapat tanah yg tingkat kekerasannya sedang yaitu tanah humus

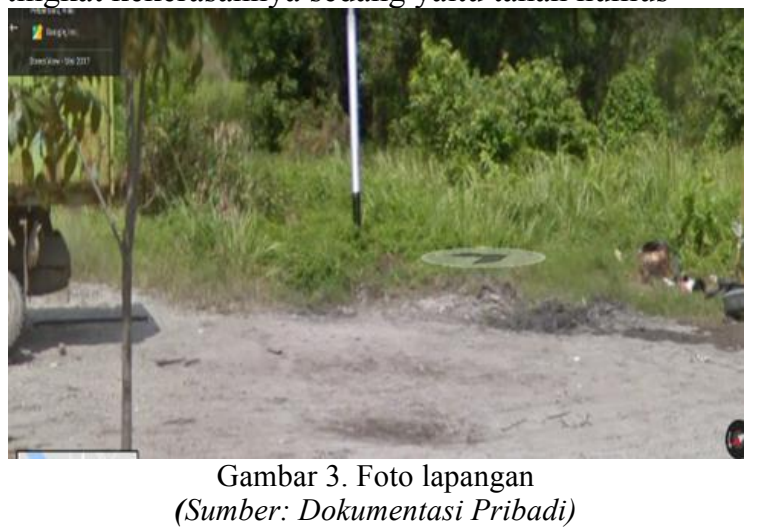

Site sendiri memiliki topografi tanah yang relatif datar sehingga hal ini sedikit diuntungkan dikarnakan tanggapan pada tapak seperti cut and feel tidak wajib dilakukan pada kondisi tapak sendiri

Lahan yang akan dibangun digeser beberapa meter. Selain untuk mengikuti peraturan yang berlaku pada tapak, hal ini bertujuan untuk penrtimbangan dampak sungai pada bangunan

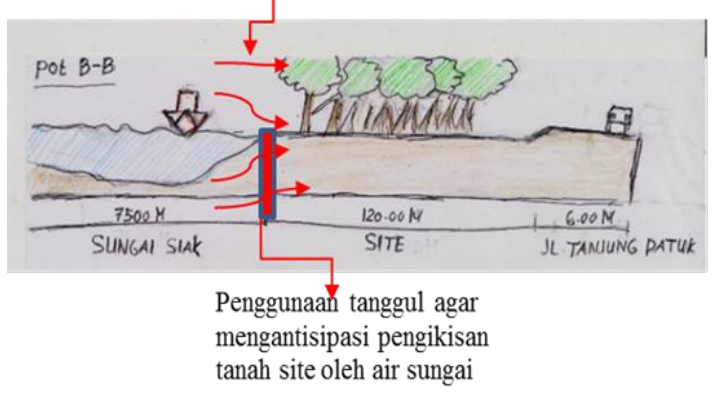

Gambar 3. Sketsa tangan
(Sumber: Dokumentasi Pribadi

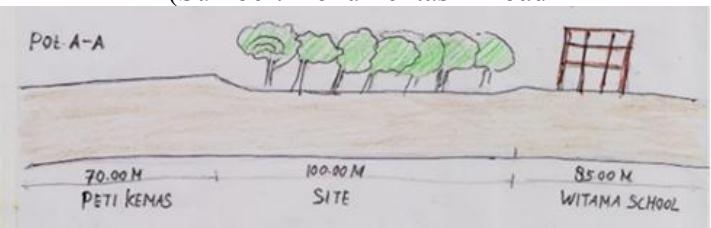

Gambar 4. Sketsa tangan

(Sumber: Dokumentasi Pribadi

\subsection{Analisis Sirkulasi}

Pada kondisi Kondisi eksisting tapak hanya terdapat satu sirkulasi yaitu sirkulasi yang berda di jalan tanjung datun, namun karna site berada di pinggriran sungai siak yang memiliki potensi maka nantinya akan diadakan penambahan sirkulasi yang berasal dari sungai siak yaitu dengan merencanakan pembuatan dermaga sehingga nantinya memiliki sirkulasi yang berasal dri sungai

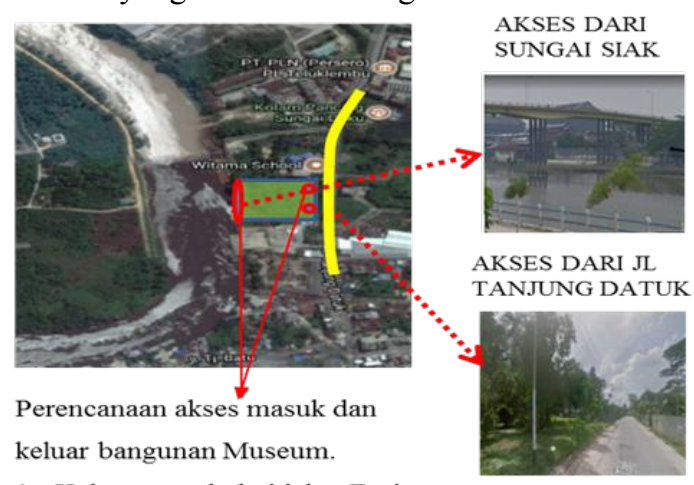

1. Keluar masuk dari jalan Tanjung Datuk

2. Keluar masuk melalui akses sungai

Gambar 5. rencana sirkulasi (Sumber: Dokumentasi Pribadi)

\subsection{Analisis Vegetasi}

Vegetasi diperlukan dalam penghawaan alami pada sebuah bangunan. Pada site sendiri hawa yang terdapat berasal dari hembusan angin yang berada di sungai.pada site sendiri cukup lumayan banyak terdapat vegetasi merupa pohon mahoni yang nantinya akan dipertahankan guna peneduh serta penyuplai hawa alami pada museum. 
3.6. Analisis Aktifitas dan Kebutuhan Ruang 3.6.1 Pengelola

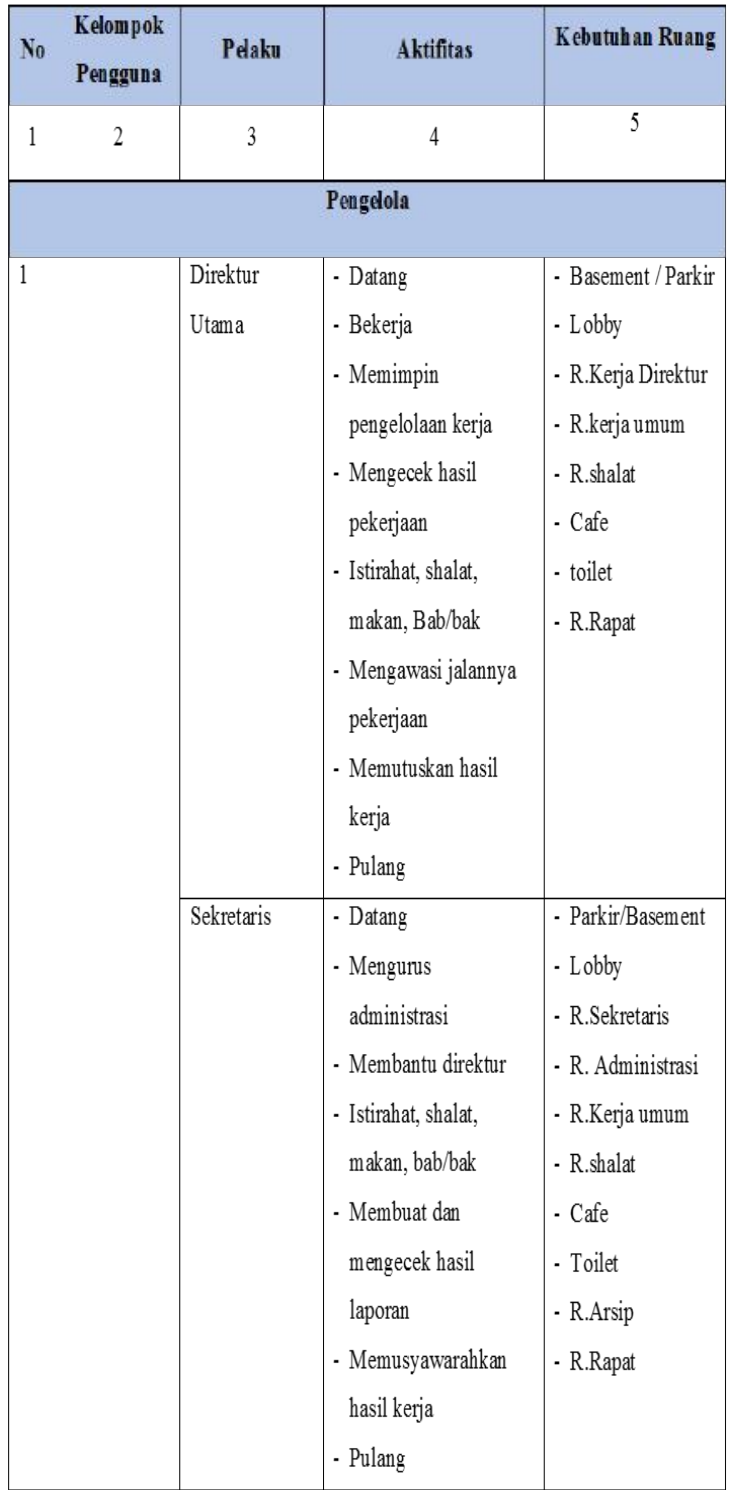

\begin{tabular}{|c|c|c|}
\hline Humas & $\begin{array}{l}\text { - Datang, Parkir } \\
\text { - kerja bidang } \\
\text { hubungan masyarakat } \\
\text { - Evaluasi laporan kerja } \\
\text { - Istirahat, shalat, } \\
\text { makan, Bab/bak } \\
\text { - Memusyawarakan } \\
\text { laporan kerja } \\
\text { - Pulang }\end{array}$ & $\begin{array}{l}\text { - Parkir/Basement } \\
\text { - Lobby } \\
\text { - R.kerja humas } \\
\text { - R.Kerja umum } \\
\text { - R.shalat } \\
\text { - Cafe } \\
\text { - Toilet } \\
\text { - R.Rapat }\end{array}$ \\
\hline Kuratorial & $\begin{array}{l}\text { - Datang } \\
\text { - Melakukan } \\
\text { penyelenggaraan, } \\
\text { mengawasi, } \\
\text { memperhatikan, } \\
\text { pengumpulan koleksi } \\
\text { - Pendataan koleksi } \\
\text { - Istirahat, shalat, } \\
\text { makan, Bab/bak } \\
\text { - Musyawarah } \\
\text { pengesahan data } \\
\text { koleksi } \\
\text { - Pulang }\end{array}$ & $\begin{array}{l}\text { - Basement / Parkir } \\
\text { - Lobby } \\
\text { - R. kuratorial } \\
\text { - R.kerja umum } \\
\text { - R.shalat } \\
\text { - Cafe } \\
\text { - Toilet } \\
\text { - R.Rapat }\end{array}$ \\
\hline $\begin{array}{l}\text { Konservasi \& } \\
\text { Preparasi }\end{array}$ & $\begin{array}{l}\text { - Datang, Parkir } \\
\text { - Melakukan perawatan, } \\
\text { penjagaan karya } \\
\text { - Menyusun Kerangka } \\
\text { kegiatan berkelanjutan } \\
\text { - Istirahat, shalat, } \\
\text { makan, BAB/BAK } \\
\text { - Musyawarah } \\
\text { pengesahan kerangka } \\
\text { kegiatan berkelanutan } \\
\text { - Pulang }\end{array}$ & $\begin{array}{l}\text { - Basement / Parkir } \\
\text { - Lobby } \\
\text { - R. konservasi dan } \\
\text { preparasi } \\
\text { - R. kerja Umum } \\
\text { - R.shalat } \\
\text { - Cafe } \\
\text { - Toilet } \\
\text { - R.Rapat }\end{array}$ \\
\hline $\begin{array}{l}\text { Bimbingan } \\
\text { dan publikasi }\end{array}$ & $\begin{array}{l}\text { - Datang } \\
\text { - Mengarahkan } \\
\text { pengujung serta } \\
\text { menjelaskan karya } \\
\text { dengan metode } \\
\text { edukatif } \\
\text { - Membuat laporan } \\
\text { kerja } \\
\text { - Istirahat, Shalat, } \\
\text { makan, BAB/BAK } \\
\text { - Musyawarah laporan } \\
\text { kerja } \\
\text { - Pulang }\end{array}$ & $\begin{array}{l}\text { - Basement / Parkir } \\
\text { - Lobby } \\
\text { - R.Pamer } \\
\text { - R.publikasi } \\
\text { - R. kerja umum } \\
\text { - R.Shalat } \\
\text { - Cafe } \\
\text { - Toilet } \\
\text { - R.Rapat }\end{array}$ \\
\hline $\begin{array}{l}\text { Registrasi dan } \\
\text { dokumentasi }\end{array}$ & $\begin{array}{l}\text { - Datang } \\
\text { - Meregistrasi dan } \\
\text { membuat dokumentasi } \\
\text { terhadap karya } \\
\text { - Membuat laporan } \\
\text { hasil kerja } \\
\text { - Istirahat, shalat, } \\
\text { makan, BAB/BAK } \\
\text { - Musyawarah } \\
\text { pengesahan laporan } \\
\text { kerja } \\
\text { - Pulang }\end{array}$ & $\begin{array}{l}\text { - Basement / Parkir } \\
\text { - Lobby } \\
\text { - R.Registrasi dan } \\
\text { Dokumentasi } \\
\text { - R.Kerja umum } \\
\text { - R.shalat } \\
\text { - Cafe } \\
\text { - Toilet } \\
\text { - R.Rapat }\end{array}$ \\
\hline
\end{tabular}


3.6.2 Bagian Pengelolaan

\begin{tabular}{|c|c|c|c|}
\hline \multicolumn{4}{|c|}{ Bagian Pengelolaan Bangunan } \\
\hline $\begin{array}{l}\text { Sub bagian } \\
\text { pengelola }\end{array}$ & $\begin{array}{l}\text { Petugas } \\
\text { Keamanan }\end{array}$ & \begin{tabular}{|l} 
- Datang \\
- Mengawasi \\
pengunjung \\
- Mengatur pengunjung \\
- Memantau koleksi \\
museum \\
- Istirahat, shalat, \\
makan, BABBBAK \\
- Lanjut kerja \\
- pulang
\end{tabular} & $\begin{array}{l}\text { - Basement / Parkir } \\
\text { - Pos Jaga } \\
\text { - R.CCTV } \\
\text { - R.shalat } \\
\text { - Cafe } \\
\text { - Toilet }\end{array}$ \\
\hline $\begin{array}{l}\text { Sub bagian } \\
\text { pengelola }\end{array}$ & \begin{tabular}{|l} 
Bagian \\
Pemeliharaan \\
\& Cleaning \\
service
\end{tabular} & \begin{tabular}{|l} 
- Datang \\
- Bekerja sesuai \\
kegiatan \\
- Istirahat, Shalat, \\
makan, BAB/BAK
\end{tabular} & $\begin{array}{l}\text { - Basement / Parkif } \\
\text { - Lobby } \\
\text { - R.Kerja } \\
\text { Workshop } \\
\text { - R.genset } \\
\text { - R.me } \\
\text { - R.pompa } \\
\text { - Gudang } \\
\text { - R. shalat } \\
\text { - R.persiapan } \\
\text { - R. diskusi } \\
\text { - Cafe } \\
\text { - Toilet }\end{array}$ \\
\hline
\end{tabular}

3.6.3 Pengunjung

\begin{tabular}{|c|c|c|c|c|}
\hline \multicolumn{5}{|c|}{ Pengunjung } \\
\hline 2 & Pengunjung & \begin{tabular}{|l} 
Masyarakat \\
Umum \& \\
Pelajar
\end{tabular} & $\begin{array}{l}\text { - Datang } \\
\text { - Melihat karya-karya } \\
\text { - Merasakan suasana } \\
\text { museum } \\
\text { - Rekreasi } \\
\text { - Berkeliling } \\
\text { - Melihat buku karya } \\
\text { - Istirahat, shalat, } \\
\text { makan, BAB/BAK } \\
\text { - Membaca buku } \\
\text { - pulang }\end{array}$ & $\begin{array}{l}\text { - Basement / Parkir } \\
\text { - Lobby } \\
\text { - R.Pameran } \\
\text { - R.audiotorium } \\
\text { - Pustaka } \\
\text { - R.shalat, } \\
\text { - Café } \\
\text { - Galeri } \\
\text { - Toilet } \\
\text { - R.wudhu }\end{array}$ \\
\hline
\end{tabular}

3.6.4 Penyewa

\begin{tabular}{|l|l|l|l|l|}
\hline \multicolumn{3}{|c|}{ Penyewa } \\
\hline 12 & Penyewa & Retail / Non & - Datang & - Basement / Parkir \\
& & Retail & - Melayani Pengunjung & - R.Retail / Sewa \\
& & - Mengikuti acara & - R. shalat \\
& & - Istirahat, shalat, & - cafe \\
& & makan, BAB/BAK & - Toilet \\
& & - Lanjut kegiatan & \\
& & - Pulang & \\
\hline
\end{tabular}

\subsection{Analisis Besaran Ruang}

Fasilitas pengelola museum

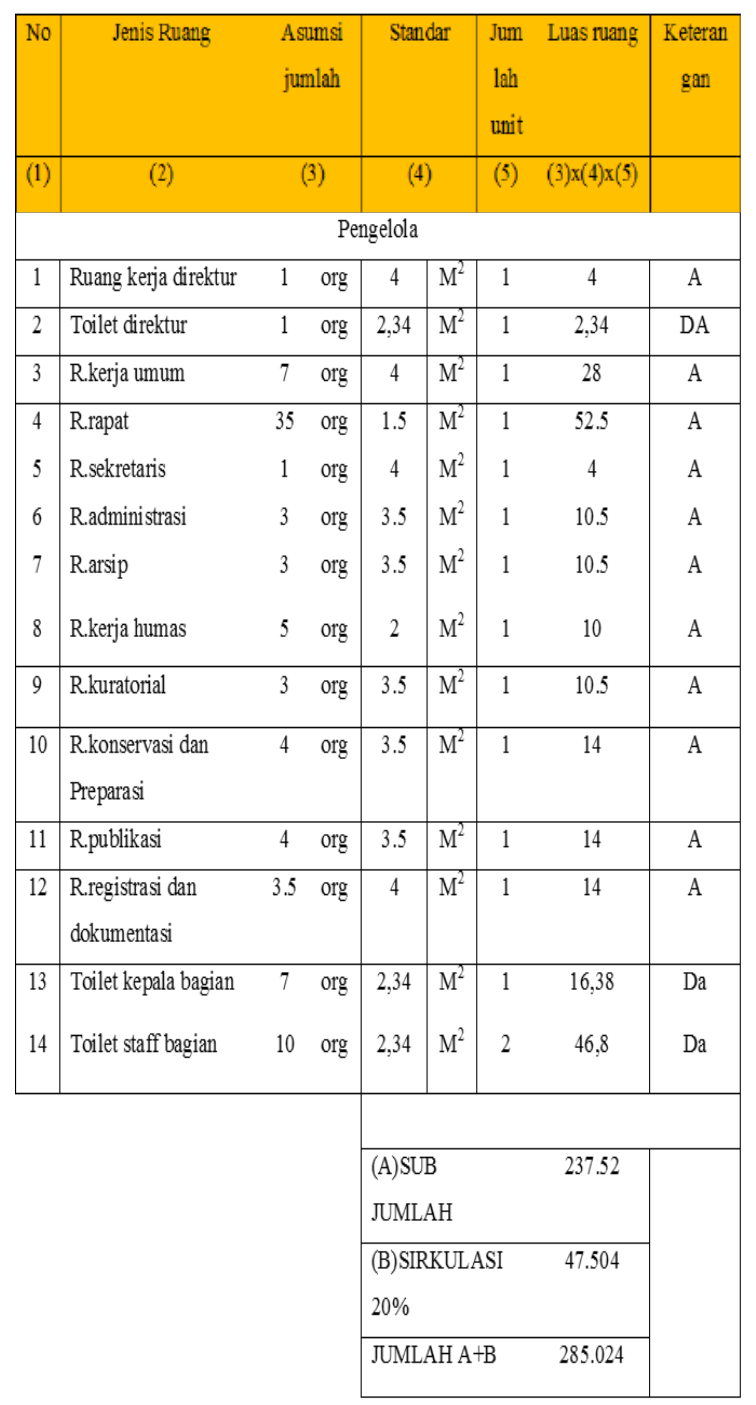


Fasilitas utama museum

\begin{tabular}{|c|c|c|c|c|c|c|c|c|}
\hline $\mathrm{N}$ & Jenis Ruang & \multicolumn{2}{|c|}{$\begin{array}{l}\text { Asumsi } \\
\text { jumlah }\end{array}$} & \multicolumn{2}{|c|}{ Standar } & $\begin{array}{l}\text { Jum } \\
\text { lah } \\
\text { unit }\end{array}$ & Luas ruang & $\begin{array}{l}\text { Keteran } \\
\text { gan }\end{array}$ \\
\hline (1) & (2) & \multicolumn{2}{|c|}{ (3) } & \multicolumn{2}{|c|}{ (4) } & (5) & $(3) x(4) x(5)$ & \\
\hline \multicolumn{9}{|c|}{ Utama } \\
\hline 1 & Lobi & 50 & org & 2 & $\mathrm{M}^{2}$ & 1 & 100 & A \\
\hline 2 & R.tiket & 10 & org & 8 & $\mathrm{M}^{2}$ & 1 & 80 & A \\
\hline 3 & Toilet L oby & 5 & org & 2,34 & $\mathrm{M}^{2}$ & 2 & 23,4 & $\mathrm{DA}$ \\
\hline 4 & R.melayu & 100 & org & 2 & $\mathrm{M}^{2}$ & 1 & 200 & A \\
\hline 5 & R.biografi & 100 & org & 2 & $\mathrm{M}^{2}$ & 1 & 200 & A \\
\hline 6 & R.karya & 100 & org & 2 & $\mathrm{M}^{2}$ & 1 & 200 & A \\
\hline 7 & R.Prestasi & 100 & org & 2 & $\mathrm{M}^{2}$ & 1 & 200 & A \\
\hline 8 & R.apresiasi & 100 & org & 2 & $\mathrm{M}^{2}$ & 1 & 200 & A \\
\hline \multirow[t]{5}{*}{9} & R.galeri & 200 & org & 2.5 & M2 & 1 & 500 & A \\
\hline & & & & \multirow{2}{*}{\multicolumn{3}{|c|}{$\begin{array}{l}\text { (A)SUB } \\
\text { JUMLAH }\end{array}$}} & 1703,4 & \\
\hline & & & & & & & & \\
\hline & & & & \multicolumn{3}{|c|}{$\begin{array}{l}\text { (B)SIRKULASI } \\
20 \%\end{array}$} & 340.68 & \\
\hline & & & & \multicolumn{3}{|c|}{ JUMLAH A+B } & 2044.08 & \\
\hline
\end{tabular}

Fasilitas penunjang museum

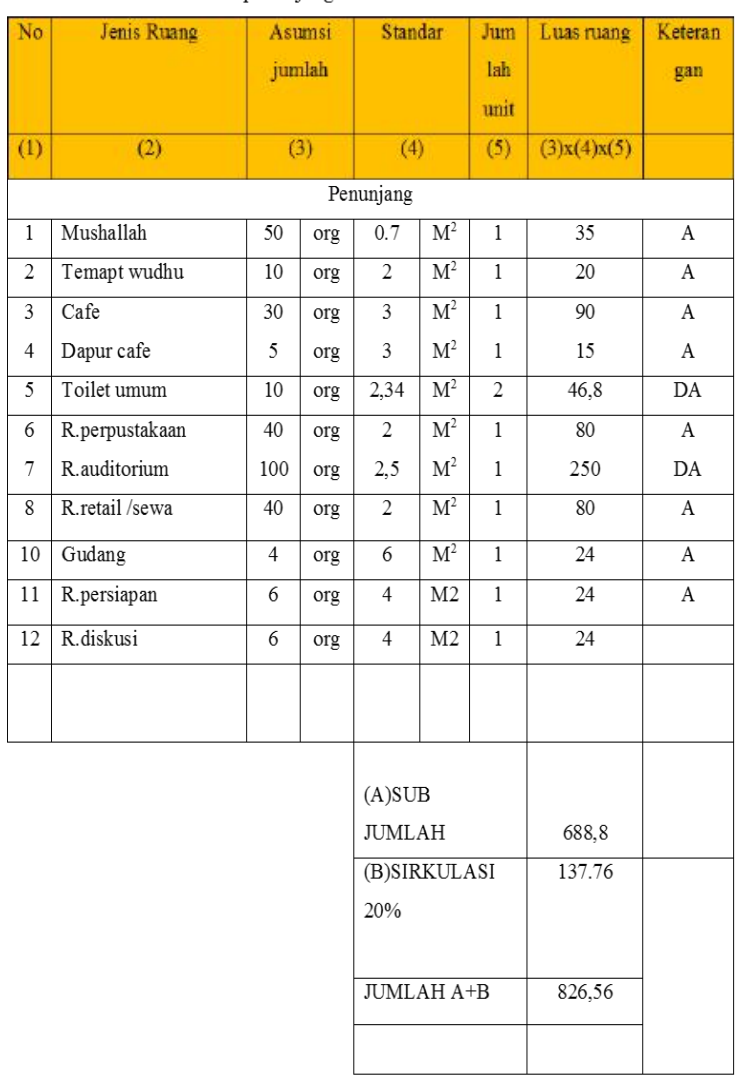

Fasilitas service museum

\begin{tabular}{|c|c|c|c|c|c|c|c|c|}
\hline $\begin{array}{l}\mathrm{N} \\
\mathrm{o}\end{array}$ & Jenis Ruang & \multicolumn{2}{|c|}{$\begin{array}{l}\text { Asumsi } \\
\text { jumlah }\end{array}$} & \multicolumn{2}{|c|}{ Standar } & $\begin{array}{l}\text { Jum } \\
\text { lah } \\
\text { unit }\end{array}$ & Luas ruang & $\begin{array}{c}\text { Keteran } \\
\text { gan }\end{array}$ \\
\hline (1) & (2) & \multicolumn{2}{|c|}{ (3) } & \multicolumn{2}{|c|}{ (4) } & (5) & (3) $\mathrm{x}(4) \times(5)$ & \\
\hline \multicolumn{9}{|c|}{ Service } \\
\hline 1 & R.jaga & 4 & org & 2,25 & $\mathrm{M}^{2}$ & 1 & 9 & A \\
\hline 2 & R.cctv & 3 & org & 3 & $\mathrm{M}^{2}$ & 1 & 9 & A \\
\hline 3 & R.genset & 4 & org & 4 & $\mathrm{M}^{2}$ & 1 & 16 & A \\
\hline 4 & R.me & 4 & org & 1,2 & $\mathrm{M}^{2}$ & 1 & 4,8 & A \\
\hline 5 & R.pompa & 2 & org & 7 & $\mathrm{M}^{2}$ & 1 & 14 & A \\
\hline \multirow[t]{4}{*}{6} & Toilet & 1 & org & 2,34 & $\mathrm{M}^{2}$ & 1 & 2,34 & $\mathrm{DA}$ \\
\hline & & & & \multicolumn{3}{|c|}{$\begin{array}{l}\text { (A)SUB } \\
\text { JUMLAH }\end{array}$} & 55,14 & \\
\hline & & & & \multicolumn{3}{|c|}{$\begin{array}{l}\text { (B)SIRKULASI } \\
20 \%\end{array}$} & 11.028 & \\
\hline & & & & \multicolumn{3}{|c|}{ JUMLAH A+B } & 66,168 & \\
\hline
\end{tabular}

Fasilitas service museum

\begin{tabular}{|c|c|c|c|c|c|c|c|c|}
\hline $\begin{array}{l}\mathrm{N} \\
0\end{array}$ & Jenis Ruang & \multicolumn{2}{|c|}{$\begin{array}{l}\text { Asumsi } \\
\text { jumlah }\end{array}$} & \multicolumn{2}{|c|}{ Standar } & $\begin{array}{l}\text { Jum } \\
\text { lah } \\
\text { unit }\end{array}$ & Luas ruang & $\begin{array}{l}\text { Keteran } \\
\text { gan }\end{array}$ \\
\hline (1) & (2) & \multicolumn{2}{|c|}{ (3) } & \multicolumn{2}{|c|}{ (4) } & (5) & (3) $\mathrm{x}(4) \mathrm{x}(5)$ & \\
\hline \multicolumn{9}{|c|}{ Service } \\
\hline 1 & R.jaga & 4 & org & 2,25 & $\mathrm{M}^{2}$ & 1 & 9 & A \\
\hline 2 & R.cctv & 3 & org & 3 & $\mathrm{M}^{2}$ & 1 & 9 & A \\
\hline 3 & R.genset & 4 & org & 4 & $\mathrm{M}^{2}$ & 1 & 16 & A \\
\hline 4 & R.me & 4 & org & 1,2 & $\mathrm{M}^{2}$ & 1 & 4,8 & A \\
\hline 5 & R.pompa & 2 & org & 7 & $\mathrm{M}^{2}$ & 1 & 14 & A \\
\hline \multirow[t]{5}{*}{6} & Toilet & 1 & org & 2,34 & $\mathrm{M}^{2}$ & 1 & 2,34 & $\overline{\mathrm{DA}}$ \\
\hline & & & & \multirow{2}{*}{\multicolumn{3}{|c|}{$\begin{array}{l}\text { (A)SUB } \\
\text { JUMLAH }\end{array}$}} & 55,14 & \\
\hline & & & & & & & & \\
\hline & & & & \multicolumn{3}{|c|}{$\begin{array}{l}\text { (B)SIRKULASI } \\
20 \%\end{array}$} & 11.028 & \\
\hline & & & & \multicolumn{3}{|c|}{ JUMLAH A+B } & 66,168 & \\
\hline
\end{tabular}

Tabel 3.7.Tabel Besaran Ruang (Sumber: Analisis Pribadi)

\begin{tabular}{|l|l|l|}
\hline \multicolumn{2}{|c|}{ Rekapitulasi } \\
\hline No & \multicolumn{1}{|c|}{ Nama Fasilitas } & \multicolumn{1}{|c|}{ Luas } \\
\hline 1. & Fasilitas pengelola museum & 285.024 \\
2. & Fasilitas utama museum & 2044.08 \\
3. & Fasilitas penunjang museum & 826,56 \\
4. & Fasilitas service museum & 66,168 \\
5. & Fasilitas Parkir museum & 954 \\
\hline \multicolumn{2}{|c|}{ Total luas bangunan } & 4175,832 \\
\hline
\end{tabular}

\subsection{Analisis Aspek Bangunan}

Pada analisis banguan museum Tenas Effendy sendiri bentuk dasar bangunan memakai 2 unsur bentuk yaitu penggabungan bentuk antara persegi dan segitiga .Hal ini berdasarkan pertimbangan bentuk dasar yang biasa digunakan pada bangunan melayu. Bagian bagian yang 
terdapat pada rumah melayu pada umumnya yaitu :

-Bagian kaki,(bawah)

Biasanya pada rumah melayu sendiri merupakan panggung,dibawah panggung biasanya difungsikan sebagai perletakan hewan ternak atau juga perletakan sampan

-Bagian badan(tengah)

Pada bangunan tengah dari bangunan melayu merupakan tempat yang berfungsi sebagai melakukan aktifitas aktifitas sehari hari. Pada bangunan tengah terdiri dari beberapa ruang seperti ruang tamu, ruang perkumpulan, ruang keluarga, kamar, dll

-Bagian kepala(Atap atau loteng)

Pada bagian atap merupakan merupakan bagian yang berfungsi untuk melindungi bagian badan dan kaki pada bangunan melayu, namun pada dahulunya bagian ini ada difungsikan sebagai penyimpanan benda benda seperti padi dan lain lain.

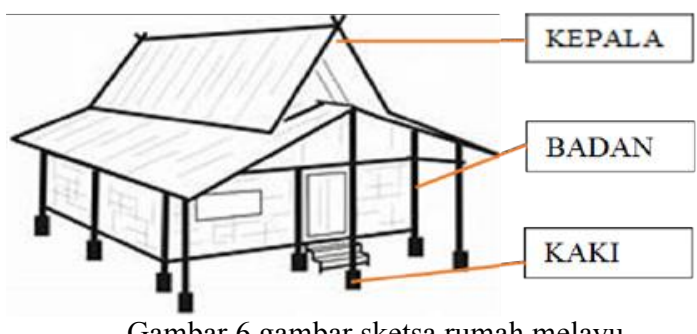

Gambar 6.gambar sketsa rumah melayu

(Sumber:http://ejudy.duckdns.org/sketsa-gambar-rumahadat-riau-3880.html)

Pada bangunan melayu sendiri sudah sejak lama sudah mempertimbangkan keadaan alam sekitar, bisa dikatakan bangunan melayu tersebut didirikan berdasarkan wawasan lingkungan sekitar seperti dengan adanya banyak jendela sehingga bertujuan agar sirkulasi udara pada bangunan dapat berfungsi dengan baik, panggung yang merupakan pertimbangan terhadap banjir serta pertimbangan terhadap gangguan hewan buas serta dari dulu bangunan-bangunan tradisional sudah menerapkan ventilasi silang terlebih dahulu

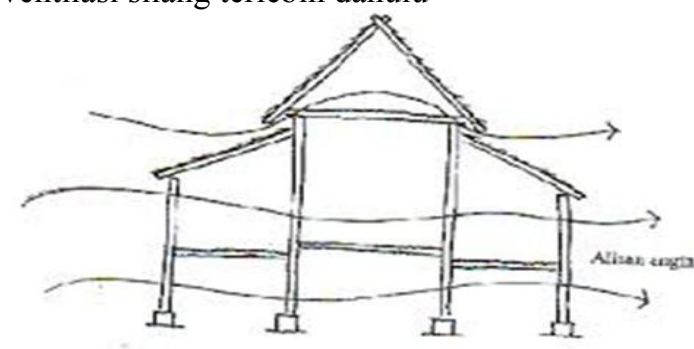

Gambar 7.sketsa sirkulasi udara

melayu(Sumber:http://ejudy.duckdns.org/sketsa-gambarrumah-adat-riau-3880.html)

\subsection{Konsep Dasar Perancangan}

Konsep dasar perancangan museum Tenas Effendy nantinya menggunakan konsep arsitektur melayu,dimana arsitekturmelayu merupakan arsitektur yang berkembang didaerah melayu dengan ciri bentuk panggung, mempunyai berbagai macam ornamen yang memiliki arti tersendiri,tanggap terhadap kondisi alam sekitar yang mana memiliki banyak bukaan serta ciri lainnya
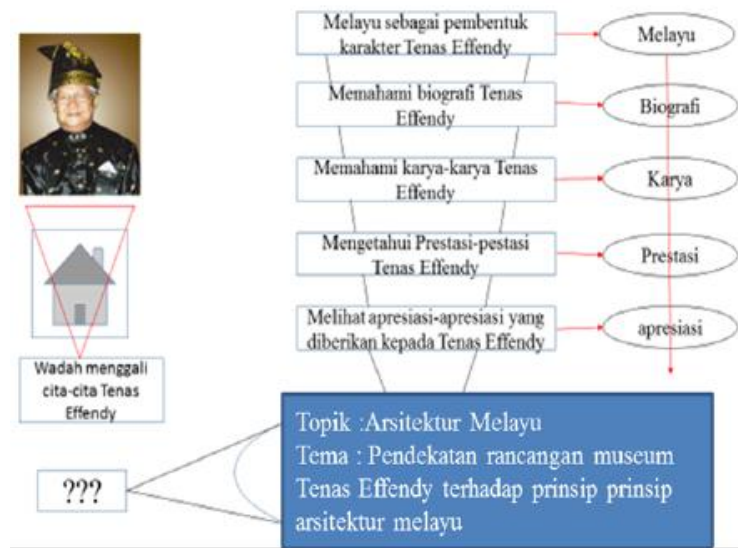

Gambar 8. Konsep dasar perancangan (Sumber: Konsep Pribadi)

\subsection{Konsep Zoning Kawasan}

Zoning merupakan pengelompokan beberapa zona dalam merancang, adapun pembagian beberapa zona sebagai berikut :

1. Zona Parkir Kapal (Penambahan dermaga)

Merencanakan penambahan zona parkir yang diperuntukkan untuk perahu berupa dermaga yang ditujukan untuk pengunjung meseum, supaya penambahan pencapaian lokasi terhadap site.

2. Zona Bangunan

Zona bangunan museum dibagi beberapa bagian, dimana bangunan penerima berdekatan langsung dengan jalan tangjung datuk, hal ini bertujuan untuk akses pencapaian pengungjung serta memberikan arah atau sirkulasi pada pengunjaung. Bangunan pengelola dan servis terletak pada tengah site sehingga dapat memantau langsung di setiap jalannnya aktifitas museum. Sedangkan perletakan ruang pamer berurutan berdasarkan alur cerita dan memiliki sirkulasi pulak balik.

3. Zona Rekreasi

Dengan letaknya ya berada di kawasan sungai siak yang merupakan kawasan yang memiliki view baik maka bisa menjadikan museum tenas Effendy sebagai sarana rekreasi yang cukup baik 


\subsection{Konsep Zoning Site}

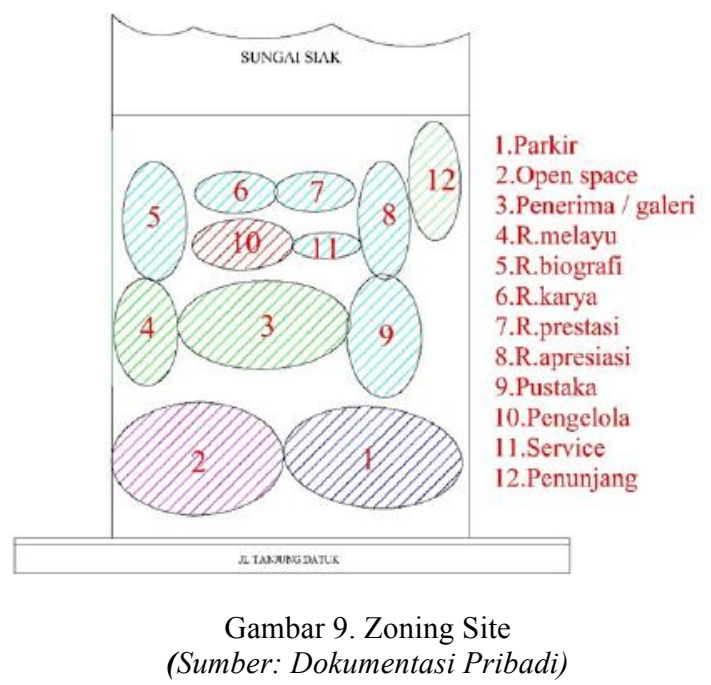

3.12. Konsep Perwujudan Arsitektur Tradisional

perancangan museum tenas Effendy merupakan bentuk bangunan melayu pada umumnya dimana bangunan tersebut merupakan bangunan panggung, berbentuk persegi panjang, atap yang digunakan adalah atap lipat kajang, memiliki jendela sebagai penghawaan alami, memiliki ornamen serta hiasan pada umumnya dengan arti atau maksud ornamen tertentu.

Penggunaan hiasannya serta ornamennya antara lain selembayung, sayap layang-layang, singap/ bidai, lebah begayut,itik pulang petang, itik sekawan, lambai-lambai dan lainnya

\subsection{Konsep Ruang Dalam}

Bentuk Ruang dalam akan disesuaikan dengan alur dari cerita museum sehingga hal ini akan mengarahkan pengunjung sesuai dengan arah dari cerita tersebut.

\subsection{Konsep Ruang Luar}

Konsep ruang luar sendiri lebih mengarah terhadap menampilkan ciri dari bangunan melayu,seperti panggung, penggunaan ornamen, ventilasi yang banyak, jendela yang banyak, mengguanakan atap lipat kajang serta ciri ciri lainnya

\subsection{Hasil Perancangan}

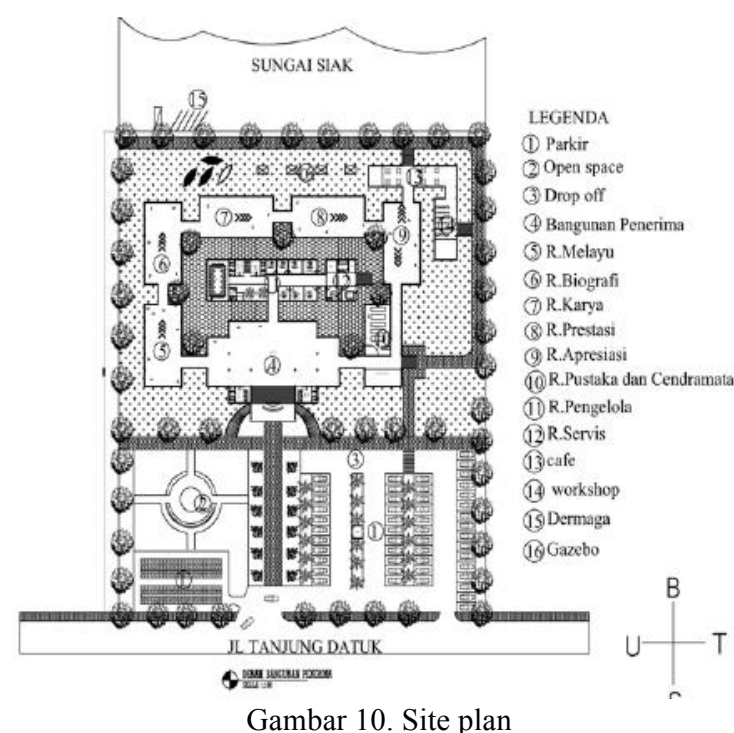

(Sumber: Dokumentasi Pribadi)
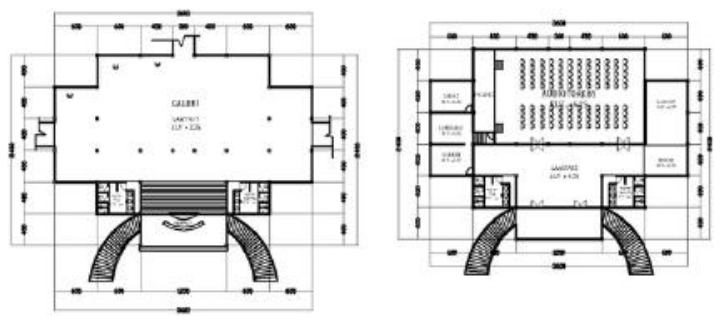

Gambar 11. Denah massa Penerima

(Sumber: Dokumentasi Pribadi)
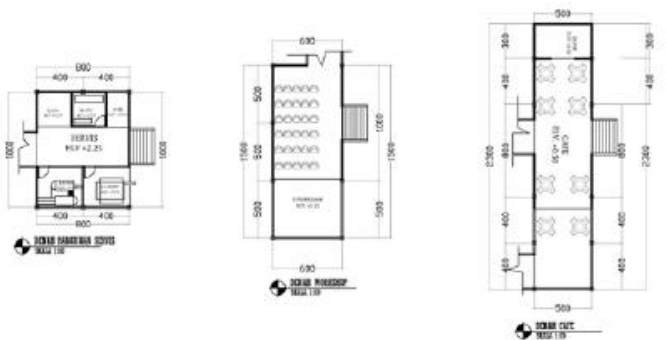

Gambar 12. Denah servis, wokshop, dan cafe (Sumber: Dokumentasi Pribadi)
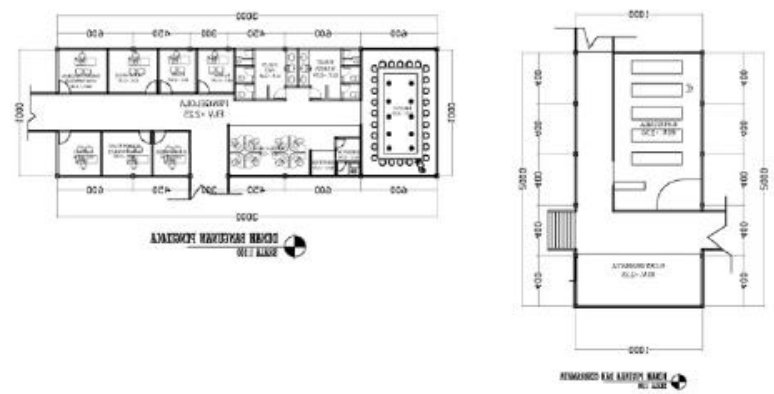

Gambar 13. Ruang Cendramata dan pengelola (Sumber: Dokumentasi Pribadi) 

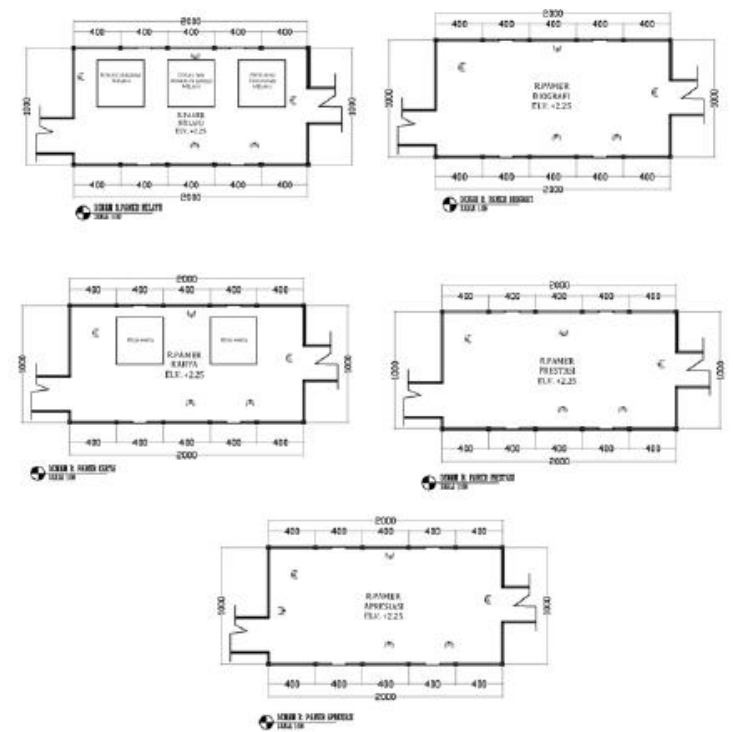

Gambar 14. Ruang Melayu, Biografi, Karya, Prestasi, dan Apresiasi

(Sumber: Dokumentasi Pribadi)

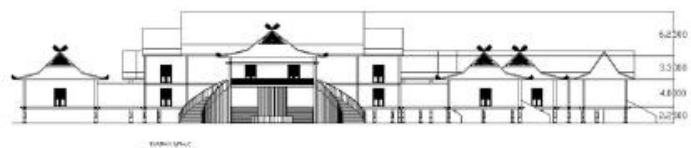

Gambar 15. Tampak Depan

(Sumber: Dokumentasi Pribadi)

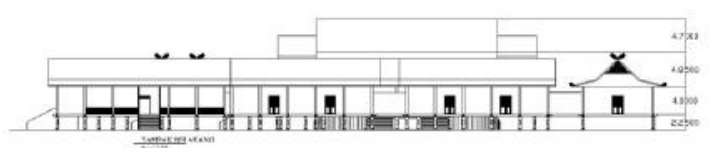

Gambar 16. Tampak Belakang

(Sumber: Dokumentasi Pribadi)

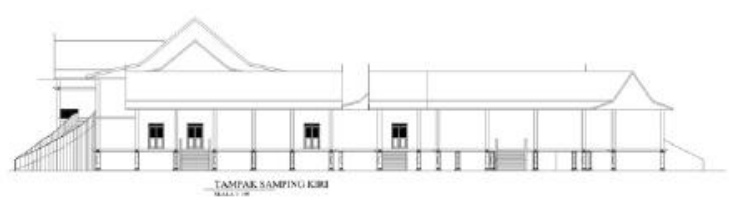

Gambar 17. Tampak Samping Kiri

(Sumber: Dokumentasi Pribadi)

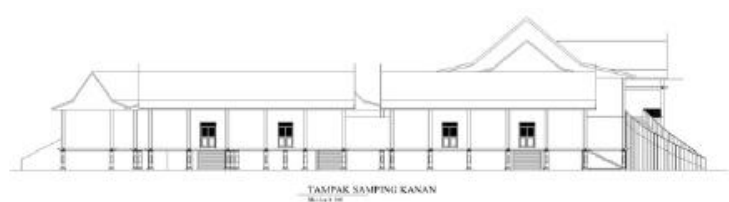

Gambar 18. Tampak Samping Kanan (Sumber: Dokumentasi Pribadi)

\section{KESIMPULAN DAN SARAN}

Jadi, "Museum Tenas Effendy di pekanbaru"adalah perancangan suatu wadah atau tempat untuk menggali cita-cita serta penyimpanan, perawatan, pengamanan karya-karya $H$. Tenas Effendy yang diwujudkan dalam bentuk eksibisi pergelaran sebuah museum yang terletak di kota Pekanbaru.

Diharapkan nantinya museum Tenas Effendy memberikan dampak yang positip terhadap perkembangan kebudayaan melayu riau serta terlaksananya kegiatan yang mewadahi fungsi rekreasi. Serta diharapkan museum ini nantinya sangat bermamfaat dalam mejadikan riau sebagai pusat kebudaayaan melayu terbesar di asia tenggara.

\section{DAFTAR PUSTAKA}

[1] D.K. Ching,Francis. 2008.Arsitektur bentuk, ruang, dan tatanan.

[2] Sudarmin, Konsep Dasar Perancangan Arsitektur Melayu.

[3] Frick, Heinz. 2007, Sistem Bentuk Struktur Bangunan, Jakarta : Kanusius

[4] Effendy ,H. Tenas dan Emmy Kadir. Ragam Hias pada Rumah Melayu Riau

[5] Almudra, Mahyudin. Mengenal sosok, pikiran dan pengabdian H. Tenas Effendy : Tegak Menjaga Tuah, Duduk Memelihara Marwah

[6] Samra, B. (2015). Konsep Ruang Dalam Rumah Lama di Kawasan Senapelan Pekanbaru. Jurnal Arsitektur Melayu dan Lingkungan, 2(1).

[7] Samra, B. (2017, December). The Characteristics Of Malay House Spatial Layout Of Pekanbaru In Accordance With Islamic Values. In IOP Conference Series: Earth and Environmental Science (Vol. 97, No. 1, p. 012049). IOP Publishing.

[8] Effendy,T. Lambang dan Falsafal dalam Seni Bina Melayu 